\title{
The Antidepressant Clomipramine Regulates Cortisol Intracellular Concentrations and Glucocorticoid Receptor Expression in Fibroblasts and Rat Primary Neurones
}

\author{
Carmine M Pariante ${ }^{*, 1}$, Abdul Hye ${ }^{2}$, Ritchie Williamson ${ }^{2}$, Andrew Makoff', Simon Lovestone ${ }^{2}$, Robert W \\ Kerwin' \\ 'Section of Clinical Neuropharmacology, Institute of Psychiatry, King's College London, London, UK; ' Department of Neuroscience, Institute of \\ Psychiatry, King's College London, London, UK
}

\begin{abstract}
Incubation of LMCAT fibroblasts cells with antidepressants potentiates glucocorticoid receptor (GR)-mediated gene transcription in the presence of cortisol, but not of corticosterone. We have suggested that antidepressants do so by inhibiting the LMCAT cells membrane steroid transporter and thus by increasing cortisol intracellular concentrations. We now confirm and extend this model to primary neuronal cultures. Clomipramine, a tricyclic antidepressant, increased the intracellular accumulation of ${ }^{3} \mathrm{H}$-cortisol, but not ${ }^{3} \mathrm{H}$ corticosterone, in LMCAT cells $(+80 \%)$ and primary rat neurones (+20\%). The latter finding is the first demonstration that a membrane steroid transporter is present in neurones. Moreover, verapamil, a membrane steroid transporter inhibitor, reduced the effects of clomipramine on the intracellular accumulation of ${ }^{3} \mathrm{H}$-cortisol in LMCAT cells. Finally, clomipramine also decreased GR expression (whole-cell Western blot) in LMCAT cells (50\% reduction) and primary rat neurones (80\% reduction). This GR downregulation can explain the reduced GR-mediated gene transcription previously described under experimental conditions that do not elicit the effects on the LMCAT cells steroid transporter. This work further supports the hypothesis that membrane steroid transporters regulating the access of glucocorticoids to the brain in vivo are a fundamental target for antidepressant action.

Neuropsychopharmacology (2003) 28, I553-156I, advance online publication, 7 May 2003; doi:I0.I038/sj.npp. I 300 I95
\end{abstract}

Keywords: antidepressants; depression; glucocorticoid receptor; hypothalamic-pituitary-adrenal axis; multidrug resistance p-glycoprotein; multidrug resistance-associated protein

\section{INTRODUCTION}

Although the effects of antidepressants on the glucocorticoid hormones and their receptors could be relevant for the therapeutic action of these drugs, the molecular mechanisms underlying these effects are unclear (Holsboer, 2000; Pariante and Miller, 2001). Patients with major depression show hyperactivity of the hypothalamic-pituitary-adrenal (HPA) axis, which is thought to participate in the development of the depressive symptoms (Nemeroff, 1996). One explanation for the HPA axis hyperactivity is an impaired feedback inhibition by the endogenous glucocorticoid cortisol. This feedback is mediated by the mineralocorticoid receptor (MR) and the glucocorticoid receptor (GR) in the brain (McEwen et al, 1997). Patients

\footnotetext{
*Correspondence: Dr CM Pariante, Section of Clinical Neuropharmacology, PO5 I, Institute of Psychiatry, King's College London, I Windsor Walk, Denmark Hill, London SE5 8AF, UK, Tel: + 44 (0) 2078480807 , Fax: + 44 (0) 207848 005I, E-mail: spjucmp@iop.kcl.ac.uk

Received 19 December 2002; revised 27 February 2003; accepted 7 March 2003

Online publication: 12 March 2003 at http://www.acnp.org/citations/ Npp03 1203480/default.pdf
}

with major depression exhibit impaired HPA negative feedback in the context of elevated circulating levels of cortisol (Nemeroff, 1996), and the GR is important in the regulation of the HPA when endogenous levels of cortisol are high (de Kloet et al, 1998). Consistent with this, the function of GR is reduced in depressed patients (GR resistance) and antidepressants reverse these putative GR changes (Pariante and Miller, 2001; Pariante et al, 2002). Specifically, studies in depressed patients, animals, and cellular models have demonstrated that antidepressants increase GR (and MR) expression, enhance GR function and promote GR nuclear translocation; this, in turn, is associated with enhanced GR-mediated negative feedback by endogenous glucocorticoids, and thus with reduced resting and stimulated HPA axis activity (Holsboer, 2000; Pariante and Miller, 2001).

In vitro studies are a fundamental tool to clarify the mechanisms underlying the effects of antidepressants on the GR. These experimental systems do not contain catecholamine reuptake sites within synaptic connections (Pariante et al, 1997, 2001a; Okugawa et al, 1999; Hery et al, 2000; Lai et al, 2003). Therefore, these systems allow the study of molecular effects that are unrelated to the inhibition of 
catecholamine uptake, the mechanism believed to be crucial in the therapeutic action of antidepressants. Antidepressants increase GR function and GR expression in neuronal cell cultures (Pepin et al, 1989; Okugawa et al, 1999; Hery et al, 2000; Lai et al, 2003), fibroblasts (Pepin et al, 1992; Pariante et al, 1997, 2001a; Miller et al, 2002), and human peripheral blood mononuclear cells (Vedder et al, 1999). However, reduced GR function in vitro by antidepressants has also been described (Pariante et al, 1997, 2001a; Budziszewska et al, 2000; Miller et al, 2002).

We have suggested that antidepressants control GR function in vitro by regulating the intracellular concentration of glucocorticoids (Pariante et al, 2001a). Glucocorticoids are excreted from fibroblasts, leukocytes, and epithelial cells by transporters of the ATP-binding cassette family (Ueda et al, 1992; Kralli and Yamamoto, 1996; Shabbits et al, 2001; Pariante et al, 2001a,b). One of these transporters, the multiple drug resistance (MDR) pglycoprotein (PGP), confers treatment resistance to tumor cells and limits the access of several drugs, including tricyclic antidepressants, to the brain (Ueda et al, 1992; Uhr et al, 2000; Shabbits et al, 2001). However, the mice (mdr1a) and human (MDR) PGPs, localized at the luminal membrane of the endothelial cells of the blood-brain barrier (BBB), also limit the access of cortisol and dexamethasone - but not of corticosterone - to mouse and human brain (Karssen et al, 2001; Meijer et al, 1998). We have described that the treatment of LMCAT fibroblasts with antidepressants inhibits a membrane steroid transporter that is virtually identical to PGP in its substrates and modulators (Ueda et al, 1992; Kralli and Yamamoto, 1996; Medh et al, 1998; Marsaud et al, 1998; Shabbits et al, 2001; Pariante et al, 2001a,b). Specifically, chemically unrelated antidepressants - the tricyclics, desipramine, amitriptyline, and clomipramine (Pariante et al, 2001a), and the selective serotonin reuptake inhibitors (SSRIs), citalopram, paroxetine (Pariante et al, 2001a), and fluoxetine (Pariante et al, unpublished) - enhance GR-mediated gene transcription in the presence of dexamethasone or cortisol, but not of corticosterone. Based on these results, we have proposed that potentiation of GR-mediated gene transcription in the presence of dexamethasone and cortisol is because of the antidepressants inhibiting the LMCAT cells' membrane steroid transporter and thus increasing the intracellular concentrations of these glucocorticoids. There are, however, some unanswered questions, which are addressed in the present study. First, the increased GR-mediated gene transcription only provides indirect evidence that antidepressants regulate glucocorticoid intracellular concentrations. Therefore, we have examined whether antidepressants directly increase the intracellular levels of radioactive glucocorticoids in LMCAT cells. Second, antidepressants regulate GR expression and function in the animal brain and neurones. Therefore, we have examined whether a similar, antidepressant-sensitive, membrane transport of glucocorticoids is present in cultured rat primary neurones. Third, a reduced GR-mediated gene transcription by antidepressants is present in LMCAT cells under experimental conditions that do not elicit the effects on the transporter, like in the absence of any glucocorticoid (Miller et al, 2002) or in the presence of corticosterone rather than cortisol (Pariante et al, 2001a). Therefore, we have examined whether these inhibitory effects are because of a reduction in GR expression by antidepressants. We have used clomipramine, a tricyclic antidepressant, because it gives the largest potentiation of GR-mediated gene transcription in the presence of cortisol, and the largest inhibition of GR-mediated gene transcription in the presence of corticosterone, among the antidepressants previously tested (Pariante et al, 2001a).

\section{MATERIALS AND METHODS}

\section{Materials}

All chemicals, unless otherwise stated, were purchased from Sigma (UK). The LMCAT cell line-L929 mouse fibroblast cells stably transfected with the mouse mammary tumor virus-chloramphenicol acetyltransferase (MMTV-CAT) reporter gene-was generously provided by ER Sanchez (Medical College of Ohio, Toledo, OH) (Sanchez et al, 1994). We have used clomipramine, at $10 \mu \mathrm{M}$, for $24 \mathrm{~h}$, as previously described (Pariante et al, 2001a). In vitro treatment with micromolar concentrations of antidepressants for at least $24 \mathrm{~h}$ have been previously used in studies that have investigated the in vitro effects of antidepressants on the GR (Pariante et al, 1997, 2001a; Vedder et al, 1999; Budziszewska et al, 2000; Miller et al, 2002; Lai et al, 2003) or on other molecular systems (Chen and Rasenick, 1995; Varga et al, 1996; Szabo et al, 1999; Xia et al, 1999; Maes et al, 1999). Moreover, this concentration resembles the therapeutic plasma and brain levels of tricyclic antidepressants (Hrdina and Dubas, 1981; Glotzbach and Preskorn, 1982). We have used verapamil $(100 \mu \mathrm{M}$ for $1.5-24 \mathrm{~h})$ to inhibit the steroid transporters, as previously described (Pariante et al, 2001a,b).

\section{LMCAT Cell Culture}

LMCAT cells were maintained in $175-\mathrm{cm}^{2}$ flasks (Marathon, UK) at $37^{\circ}$ with a $5 \% \mathrm{CO}_{2}$ and $95 \%$ air atmosphere. The culture medium was DMEM with $10 \%(\mathrm{v} / \mathrm{v})$ charcoalstripped, delipidated, heat-inactivated $\left(56^{\circ}, 30 \mathrm{~min}\right)$ bovine calf serum (Autogen Bioclear, UK) and $0.2 \mathrm{mg} / \mathrm{ml} \mathrm{G} 418$ (Geneticin) antibiotic. The levels or cortisol in this medium were $<0.1 \mathrm{nM}$ (Andrew Papadopoulos, personal communication). For measuring the intracellular accumulation of radioactive steroids, LMCAT cells were subcultured in 12well plates (Marathon, UK) and grown for $48-72 \mathrm{~h}$ (final confluency $95 \%$ ) prior to drug treatment. For Western blotting experiments, LMCAT cells were subcultured in $25 \mathrm{~cm}^{2}$ flasks (Marathon, UK) for $48-72 \mathrm{~h}$ (final confluency 95\%) prior to drug treatment.

\section{Primary Cortical Neuronal Cultures}

Neuronal cultures were prepared from embryonic day 18 rat embryos as previously described (Williamson et al, 2002). Essentially, embryos were removed and their fetal brain cortices dissected and freed of meninges. The cells were dissociated by trypsinization $(0.25 \%(\mathrm{v} / \mathrm{v})$ for $20 \mathrm{~min}$ at $37^{\circ} \mathrm{C}$ ). Trypsinization was stopped by washing three times in Neurobasal medium (Life Technologies, UK) containing $10 \%(\mathrm{v} / \mathrm{v})$ fetal calf serum (FCS) (Autogen Bioclear, UK), 
and then treated with $2 \mathrm{Kunitz}$ units/ml deoxyribonuclease 1 followed by trituration with fire-polished Pasteur pipettes. For measuring the intracellular accumulation of radioactive steroids, $1 \times 10^{6}$ primary rat brain cortical cells were plated onto poly-L-lysine $(10 \mu \mathrm{g} / \mathrm{ml})$-coated glass coverslips in 12 well tissue culture plates (Marathon, UK). For Western blotting experiments, $4 \times 10^{6}$ neurones were plated into $25 \mathrm{~cm}^{2}$ flasks (Marathon, UK). Cells were maintained in Neurobasal medium containing B27 supplement (Life Technologies, UK), $2 \mathrm{mM}$ glutamine, and $20 \mu \mathrm{g} / \mathrm{ml}$ gentamicin solution. The levels of cortisol in this medium were 0.6-0.7 nM (Andrew Papadopoulos, personal communication). Rat brain primary cells were cultured for 7 days before being used for the treatments described.

\section{Intracellular Accumulation of Radioactive Glucocorticoids}

The assay to measure intracellular accumulation of radioactive glucocorticoids has been developed from Bourgeois et al (1993). Cells were incubated with ${ }^{3} \mathrm{H}$-cortisol $(47.0 \mathrm{Ci} /$ $\mathrm{mmol}$ ) or ${ }^{3} \mathrm{H}$-corticosterone $(70.0 \mathrm{Ci} / \mathrm{mmol})$ (Amersham Pharmacia Biotech, UK), for $1.5 \mathrm{~h}$, at $37^{\circ} \mathrm{C}$ in a $\mathrm{CO}_{2}$ incubator. After three cold washes in phosphate-buffered salt solution (PBS), cells were scraped into lysis buffer (Roche Diagnostic, UK) and then transferred to vials for liquid scintillation counting. The radioactive signal, as measured by scintillation counting, is proportional to the intracellular concentration of the radioactive glucocorticoid. Results were normalized with respect to cell number by measurement of metabolic activity by cleavage of the tetrazolium salt WST-1 (Roche Diagnostic, UK). Clomipramine directly reduces cell metabolic activity only at concentrations of $100 \mu \mathrm{M}$ or higher (Pariante et al, 2001a), while cortisol does not influence cell metabolic activity for concentrations ranging $10 \mathrm{nM}-1 \mu \mathrm{M}$.

The intracellular accumulation of glucocorticoids likely reflects both GR-bound and GR-unbound signal. The ability of the radioactive glucocorticoids to bind the GR during the $1.5 \mathrm{~h}$ incubation is influenced by the degree of dissociation that occurs between GR and the endogenous ligands. This processes is dependent on temperature and $\mathrm{pH}$, and requires a period of time when the cells are incubated in steroid-free conditions (Steiner and Wittliff, 1985). Since our assay did not aim to measure GR levels, we did not include this step. Therefore, even the use of an excess of unlabelled glucocorticoids in this assay gives only an approximate measurement of the relative size of these two compartments (see Results and Discussion).

\section{Western Blotting and Densitometry Image Analysis}

The procedures for Western blotting and densitometry image analysis were previously described (Williamson et al, 2002). Briefly, cells were washed three times in ice-cold TBS (25 mM Tris, $\mathrm{pH} 8.0,140 \mathrm{mM} \mathrm{NaCl}$, and $5 \mathrm{mM} \mathrm{KCl}$ ) and lysed by scraping into hot $\left(100^{\circ} \mathrm{C}\right) 2 \times$ sodium dodecyl sulfate (SDS) polyacrylamide gel electrophoresis (PAGE) sample buffer, heated to $100^{\circ} \mathrm{C}$ for $5 \mathrm{~min}$, and then centrifuged at $15800 \mathrm{~g}(\mathrm{av})$ for $5 \mathrm{~min}$. Proteins were resolved by SDS-PAGE using $10 \%(\mathrm{w} / \mathrm{v})$ polyacrylamide. Proteins were transferred to nitrocellulose (Schleicher \& Scheull,
Germany) and submerged in blocking buffer TBS-Tween (TBS containing $0.2 \%(\mathrm{v} / \mathrm{v})$ Tween-20 and $3 \%(\mathrm{w} / \mathrm{v})$ nonfat dried milk) for $1 \mathrm{~h}$ at room temperature. Blots were incubated with the primary antibody diluted in blocking buffer overnight at $4{ }^{\circ} \mathrm{C}$. The primary antibody was the rabbit polyclonal antibody 57 (GR57) against the human GR (Affinity BioReagents, UK), $0.5 \mu \mathrm{g} / \mathrm{ml}$, as previously described (Pariante et al, 1997, 1999, 2001b). Blots were washed three times in PBS-Tween and incubated with horseradish peroxidase (HRP)-linked donkey anti-rabbit Igs (Amersham Pharmacia, UK) diluted in blocking buffer for $1 \mathrm{~h}$. After a further three washes in TBS-Tween, antibody binding was detected by an enhanced chemiluminescence (ECL) system (Amersham Pharmacia, UK). Film images from ECL-developed Western blots, developed for different times in order to ensure linearity of exposure, were analysed with a GS710 scanning densitometer utilizing the Quantity One (Bio Rad, UK) quantification software.

\section{Experimental Design}

Intracellular accumulation of ${ }^{3} \mathrm{H}$-glucocorticoids in LMCAT cells and rat cortical neurones. To study the relation between cortisol concentrations and its transport across cell membranes, we examined the intracellular accumulation of ${ }^{3} \mathrm{H}$-cortisol $(1,10,100 \mathrm{nM}$ and $1 \mu \mathrm{M})$, alone or in the presence of verapamil $(100 \mu \mathrm{M})$, in LMCAT cells. To study the GR-bound and GR-unbound signal, we examined the intracellular accumulation of ${ }^{3} \mathrm{H}$-cortisol $(50 \mathrm{nM})$ or ${ }^{3} \mathrm{H}$-corticosterone $(50 \mathrm{nM})$, alone or in the presence of an excess $(30 \mu \mathrm{M})$ of the unlabelled glucocorticoid, in LMCAT cells and rat primary neurones. To study whether rat primary neurones express a verapamil-sensitive membrane steroid transporter, we treated cells for $24 \mathrm{~h}$ with verapamil $(100 \mu \mathrm{M})$, and then examined the intracellular accumulation of ${ }^{3} \mathrm{H}$-cortisol $(50 \mathrm{nM}$ ) (verapamil was continued during the incubation with the radioactive glucocorticoid).

Effects of clomipramine on intracellular accumulation of ${ }^{3} \mathrm{H}$-cortisol and ${ }^{3} \mathrm{H}$-corticosterone in LMCAT cells and neurones. To study whether clomipramine inhibits membrane transport of glucocorticoids in LMCAT cells and rat primary neurones, we treated cells for $24 \mathrm{~h}$ with clomipramine $(10 \mu \mathrm{M})$ and then examined the intracellular accumulation of ${ }^{3} \mathrm{H}$ cortisol $(50 \mathrm{nM})$ or ${ }^{3} \mathrm{H}$-corticosterone $(50 \mathrm{nM})$ (clomipramine was continued during the incubation with the radioactive glucocorticoids). We did not incubate cells with clomipramine and the radioactive glucocorticoids for $24 \mathrm{~h}$, because the radioactive glucocorticoids would affect GR expression over such a long incubation; moreover, this design is equivalent to that used to examine the effects of clomipramine on GR expression. To study whether clomipramine increases the intracellular accumulation of radioactive cortisol in the presence of verapamil, we treated LMCAT cells for $24 \mathrm{~h}$ with clomipramine $(10 \mu \mathrm{M})$ and then examined the intracellular accumulation of ${ }^{3} \mathrm{H}$-cortisol $(50 \mathrm{nM})$ in the presence of verapamil $(100 \mu \mathrm{M})$ (and clomipramine).

Effects of clomipramine on GR protein levels in LMCAT cells and neurones. To study the effects of clomipramine on 
GR expression in LMCAT cells and rat primary neurones, we treated cells for $24 \mathrm{~h}$ with clomipramine $(10 \mu \mathrm{M})$ and then examined GR by Western blot.

\section{Statistical Analysis}

Data are presented as mean \pm standard error of the mean (SEM) of three or more independent experiments. Comparisons between treatment conditions and vehicle controls were conducted using $t$-test.

\section{RESULTS}

\section{Intracellular Accumulation of ${ }^{3} \mathrm{H}$-Glucocorticoids in LMCAT Cells and Rat Cortical Neurones}

As shown in Figure 1, there was a linear relation between ${ }^{3} \mathrm{H}$-cortisol concentrations in the media and the levels of intracellular accumulation in LMCAT cells. At all concentrations of ${ }^{3} \mathrm{H}$-cortisol, verapamil increased the intracellular levels of the glucocorticoid hormone. Based on these results, we decided to use ${ }^{3} \mathrm{H}$-cortisol $(50 \mathrm{nM})$ for all subsequent experiments. In fact, the effects by verapamil were greater between 10 and $100 \mathrm{nM}$. Moreover, we have previously shown that this concentration of cortisol induces only partial GR activation and can be successfully used to elicit the effects of antidepressants on GR function (Pariante et al, 2001a). ${ }^{3} \mathrm{H}$-corticosterone $(50 \mathrm{nM})$ was used for comparison.

In a second series of experiments, we wanted to test whether the intracellular accumulation of radioactive cortisol or radioactive corticosterone would have been lowered by an excess of unlabelled glucocorticoid, because of competition at the binding with the GR. The results of the experiments in LMCAT cells are presented in Figure 2.

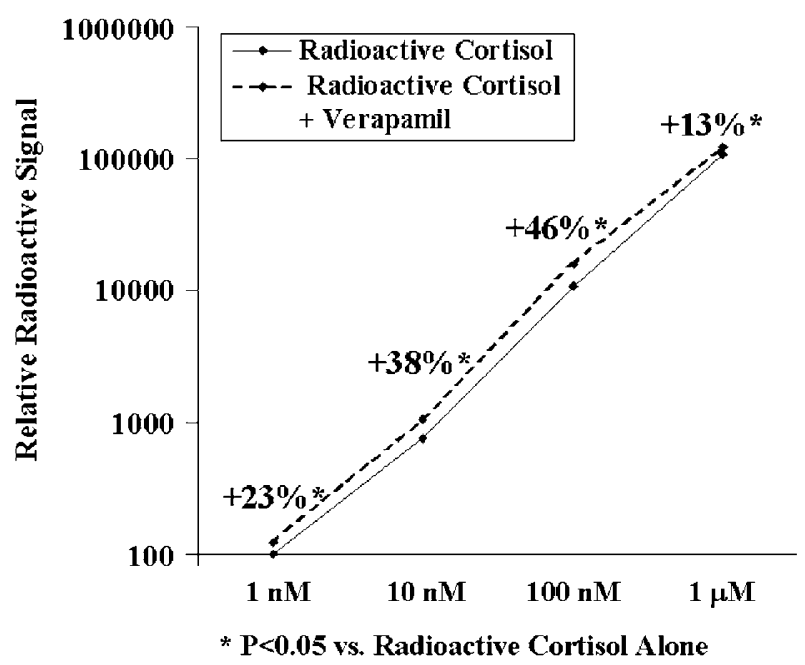

Figure I Intracellular accumulation of radioactive cortisol in LMCAT cells, alone or with verapamil. LMCAT cells were treated for $1.5 \mathrm{~h}$ with ${ }^{3} \mathrm{H}$ cortisol $(1,10,100 \mathrm{nM}$, and I $\mu \mathrm{M})$, alone or in the presence of verapamil $(\mathrm{I} 00 \mu \mathrm{M})$. Cells extracts were analyzed for relative intracellular accumulation of ${ }^{3} \mathrm{H}$-cortisol (fold accumulation relative to cells treated with ${ }^{3} \mathrm{H}$ cortisol (I nM) alone). Mean values from three independent experiments are presented in a logarithmic scale. The effects of verapamil are indicated as percentage increase compared to ${ }^{3} \mathrm{H}$-cortisol alone. The * indicates a significant $(P<0.05)$ difference between ${ }^{3} \mathrm{H}$-cortisol plus verapamil $(100 \mu \mathrm{M})$ and the corresponding concentration of ${ }^{3} \mathrm{H}$-cortisol alone.

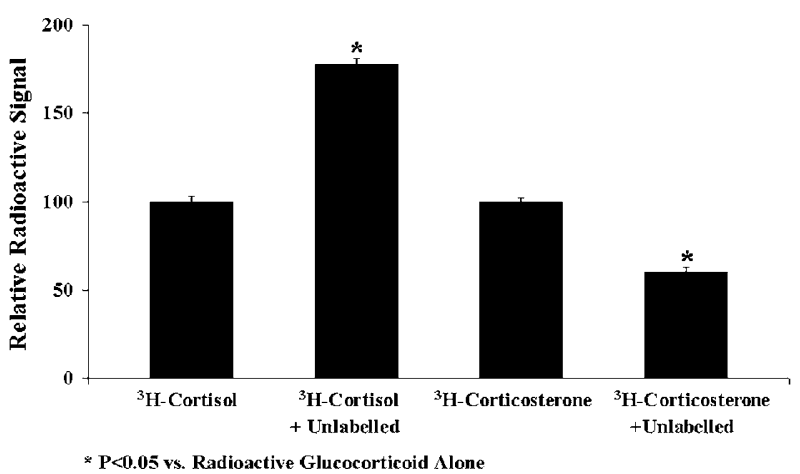

Figure 2 Intracellular accumulation of radioactive glucocorticoids in LMCAT cells, alone or with excess of unlabelled competitor. LMCAT cells were treated for $1.5 \mathrm{~h}$ with (I) ${ }^{3} \mathrm{H}$-cortisol $(50 \mathrm{nM}),(2)^{3} \mathrm{H}$-cortisol (50 nM) plus cortisol $(30 \mu \mathrm{M}),(3){ }^{3} \mathrm{H}$-corticosterone $(50 \mathrm{nM})$, and (4) ${ }^{3} \mathrm{H}$ corticosterone $(50 \mathrm{nM})$ plus corticosterone $(30 \mu \mathrm{M})$. Cell extracts were analyzed for relative intracellular accumulation (fold accumulation relative to cells treated with the radioactive glucocorticoid alone). The results are shown as the mean \pm SEM of four independent experiments. The * indicates a significant $(P<0.05)$ difference compared to the radioactive glucocorticoid alone.

Surprisingly, unlabelled cortisol induced almost an $80 \%$ increase, rather than a decrease, of the intracellular accumulation of radioactive cortisol. We interpreted these findings as showing that the unlabelled cortisol competes for the radioactive cortisol at the efflux system, thus increasing the intracellular accumulation of the radioactive cortisol. However, because corticosterone is not transported, the unlabelled corticosterone competes with the radioactive corticosterone at the GR binding site and results in a $40 \%$ reduction of the intracellular accumulation.

The results of the experiments conducted in primary neurones mirrored those in LMCAT cells using the same protocols, thus providing the first evidence that a membrane transport of cortisol is present in these cells. First, unlabelled cortisol induced a small increase of the intracellular accumulation of radioactive cortisol $(+7 \pm 4 \%, P=0.1)$, while unlabelled corticosterone induced a decrease of the intracellular accumulation of radioactive corticosterone $(-15 \pm 3 \%, P<0.05)$. Second, verapamil increased the intracellular accumulation of ${ }^{3} \mathrm{H}$ cortisol $(+174 \pm 15 \%, P<0.05)$.

Effects of Clomipramine on Intracellular Accumulation of ${ }^{3} \mathrm{H}$-Cortisol and ${ }^{3} \mathrm{H}$-Corticosterone in LMCAT Cells and Neurones

Clomipramine induced an increase in the intracellular accumulation of ${ }^{3} \mathrm{H}$-cortisol, compared to cells treated with vehicle: approximately $+80 \%$ in LMCAT cells (Figure 3 ) and $+20 \%$ in neurones (Figure 4 ). In the presence of ${ }^{3} \mathrm{H}$ corticosterone, clomipramine had no effect in LMCAT cells (Figure 3 ) and induced a small $(-11 \%)$ reduction of the intracellular concentration in neurones (Figure 4). To corroborate these findings, we tested in LMCAT cells whether clomipramine would increase the intracellular accumulation of radioactive cortisol in the presence of verapamil. If inhibition of the steroid transporter is the mechanism by which clomipramine increased intracellular accumulation of ${ }^{3} \mathrm{H}$-cortisol, this effect should decrease in 


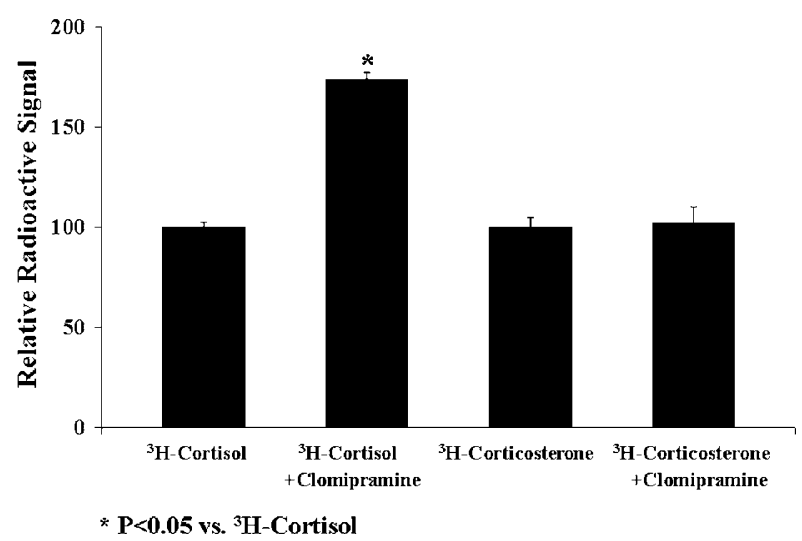

Figure 3 Intracellular accumulation of radioactive glucocorticoids in LMCAT cells, treated with vehicle or clomipramine. LMCAT cells were treated with vehicle or clomipramine $(10 \mu \mathrm{M})$ for $24 \mathrm{~h}$, and then incubated for $1.5 \mathrm{~h}$ with ${ }^{3} \mathrm{H}$-cortisol $(50 \mathrm{nM})$ or ${ }^{3} \mathrm{H}$-corticosterone $(50 \mathrm{nM})$. Clomipramine was continued during the $1.5 \mathrm{~h}$ incubation with the radioactive glucocorticoid. Cells extracts were analyzed for relative intracellular accumulation (fold accumulation relative to control cells). The results are shown as the mean \pm SEM of three independent experiments. The $*$ indicates a significant $(P<0.05)$ difference compared to control cells.

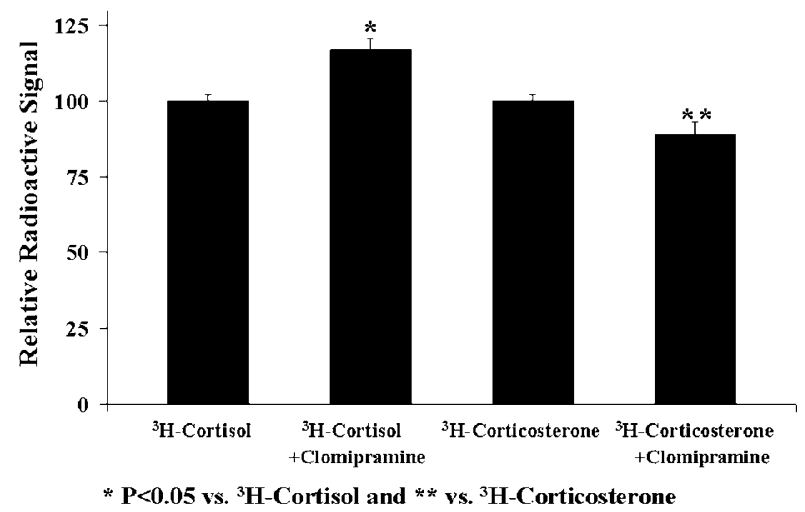

Figure 4 Intracellular accumulation of radioactive glucocorticoids in rat primary neurones, treated with vehicle or clomipramine. I-week old rat primary neurones were treated with vehicle or clomipramine $(10 \mu \mathrm{M})$ for $24 \mathrm{~h}$, and then incubated for $1.5 \mathrm{~h}$ with ${ }^{3} \mathrm{H}$-cortisol $(50 \mathrm{nM})$ or ${ }^{3} \mathrm{H}$ corticosterone $(50 \mathrm{nM})$. Clomipramine was continued during the $1.5 \mathrm{~h}$ incubation with the radioactive glucocorticoid. Cell extracts were analyzed for relative intracellular accumulation (fold accumulation relative to control cells). The results are shown as the mean \pm SEM of three independent experiments. The * indicates a significant $(P<0.05)$ difference compared to cells treated with ${ }^{3} \mathrm{H}$-cortisol alone, and $* *$ indicates a significant $(P<0.05)$ difference compared to cells treated with ${ }^{3} \mathrm{H}$-corticosterone alone.

the presence of verapamil. As hypothesized, the treatment of LMCAT cells with clomipramine in the presence of verapamil induced only a small (and not statistically significant) increase of intracellular accumulation of ${ }^{3} \mathrm{H}$ cortisol $(+17 \pm 11 \%, P=0.2)$, compared to cell treated with verapamil alone.

\section{Effects of Clomipramine on GR Protein Levels in LMCAT Cells and Neurones}

We examined the effects of clomipramine on GR expression, assessed by whole-cell Western blot, in LMCAT cells

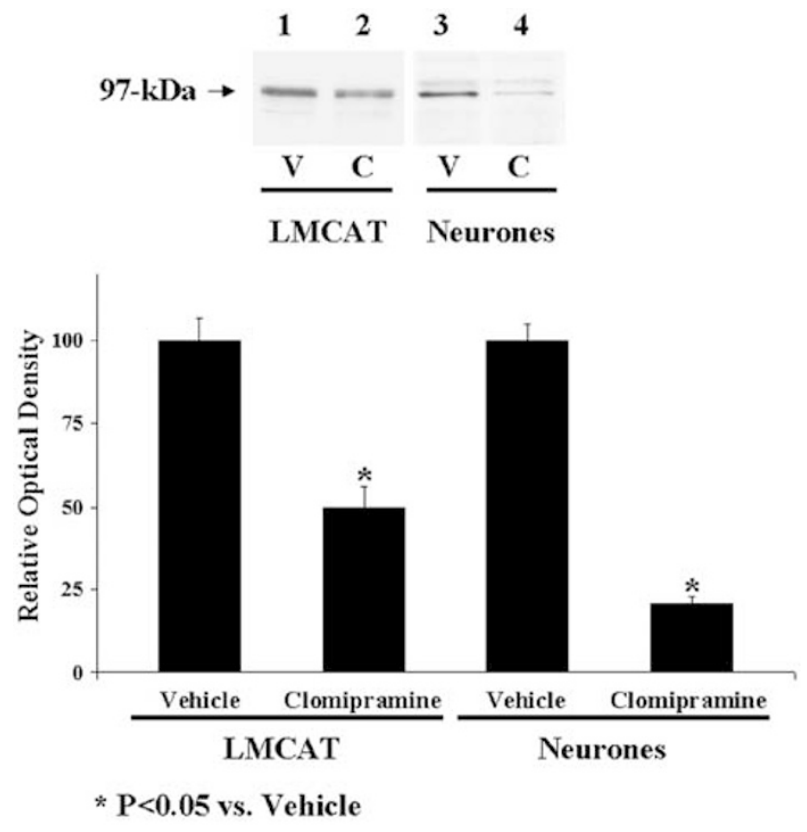

Figure 5 Western blot of the GR in LMCAT cells and rat primary neurones, treated with vehicle or clomipramine. LMCAT cells and I-week old rat primary neurones were treated with vehicle $(V)$ or clomipramine (C) $(10 \mu \mathrm{M})$ for $24 \mathrm{~h}$. Cells were lysed by scraping into hot $\left(100^{\circ} \mathrm{C}\right) 2 \times$ SDS-PAGE sample buffer. GR present in the lysates was analysed by Western blot using the anti-GR polyclonal antibody GR57 and a horseradish peroxidase-conjugated counterantibody. The GR57 recognized a prominent band at $\sim 97 \mathrm{kDa}$. Top: representative Western blots. Bottom: quantitation of GR bands, based on densitometric analysis. Results are expressed as percentage of the GR signal in the vehicle-treated cells, and are presented as mean \pm SEM of 3-4 independent experiments. The * indicates a significant $(P<0.05)$ difference compared to control cells.

and primary rat cortical neurones. Figure 5 shows representative Western blots, together with the results of the densitometric quantitation of the GR band from independent experiments. In both types of cells, the rabbit polyclonal antibody 57 (GR57) against the human GR recognized a prominent band at $\sim 97 \mathrm{kDa}$, consistent with similar experiments performed with the same antibody in the cytosolic and nuclear fractions of LMCAT cells (Pariante et al, 1997, 1999, 2001b) and in the rat brain (O'Donnell et al, 1995) or with different monoclonal antibodies anti-GR (Beck et al, 1993; Sanchez et al, 1994). Compared with vehicle (lanes 1 and 3 ), treatment with clomipramine $(10 \mu \mathrm{M}, 24 \mathrm{~h})$ (lanes 2 and 4$)$ resulted in a reduction of GR levels. This was confirmed by densitometric quantitation of the GR bands, which showed a reduction in GR signal in cells treated with clomipramine: $50 \%$ reduction in LMCAT cells and $80 \%$ reduction in neurones.

\section{DISCUSSION}

This study shows that the antidepressant clomipramine inhibits a membrane steroid transporter and thus increases intracellular concentrations of cortisol, in fibroblasts and neurones. In summary: (1) clomipramine increases the intracellular concentrations of ${ }^{3} \mathrm{H}$-cortisol, but not ${ }^{3} \mathrm{H}$ corticosterone, in LMCAT cells and primary rat neurones and (2) the effect of clomipramine on the intracellular 
accumulation of ${ }^{3} \mathrm{H}$-cortisol in LMCAT cells is reduced in the presence of the steroid transporter inhibitor verapamil.

This is the first report, to our knowledge, of a functional membrane transport of glucocorticoids in neurones. Human neuroblastoma cells express PGP (Kurowski and Berthold, 1998), and cells from the mouse hippocampal cell line HT22 express a membrane steroid transporter that is blocked by verapamil (Herr et al, 2000). However, no immunolabelling of PGP has been found in adult rat brain neurones (Matsuoka et al, 1999), although PGP and PGPlike transporters can be expressed at very low levels that are undetected by immunocytochemistry (Kralli and Yamamoto, 1996; Marsaud et al, 1998). Interestingly, immunoreactive and mRNA signals for another family of membrane transporters, the multidrug resistance-associated proteins (MRPs), have been found in rat neuronal cultures (Hirrlinger et $a l, 2002$ ) and in dysplastic neurones from brain samples of epileptic patients (Sisodiya et al, 2002). The MRPs are organic anion transporters that participate in multidrug resistance (Leslie et al, 2001). The function and expression of MRPs are modulated by cortisol (Mulder et al, 1996) and MRP-overexpressing cells are resistant to the effects of cortisol (Bergman et al, 2001). At present, however, the nature of the cortisol transporters in rat neurones is unclear.

We can only estimate the amount of GR-bound vs GRunbound radioactive signal in the cells (see Materials and methods). However, it seems clear that most of the signal is GR unbound. In LMCAT cells, the excess of corticosterone decreases the signal by $40 \%$, but the $50 \%$ reduction in GR expression by clomipramine leads to no change in intracellular accumulation of radioactive corticosterone. In neurones, the excess of unlabelled corticosterone and the $80 \%$ reduction of GR expression by clomipramine lead only to a $10-15 \%$ reduction in the intracellular accumulation of radioactive corticosterone. These results corroborate data by Karssen et al $(2001,2002)$ in mdrla PGP knockout mice, showing that brain labelling by a radioactive glucocorticoid is not reduced by an excess of the unlabelled glucocorticoid (except in the hippocampus), thus suggesting that the radioactive glucocorticoid in the brain of these animals is mostly unbound.

A second major finding in our study is that clomipramine reduces GR expression in LMCAT cells and primary rat neurones. These data are consistent with our previous results showing that $24-96 \mathrm{~h}$ of treatment with desipramine induces a $10-25 \%$ reduction in cytosolic GR binding in L929 cells; this reduction is still present after the cells have recovered for $24 \mathrm{~h}$ in media with no desipramine (Pariante et al, 1997). Since $24 \mathrm{~h}$ desipramine also induces activation and translocation of the GR from the cytoplasm to the nucleus (Pariante et al, 1997), and this is associated with a decrease of GR in the cytosolic fraction (McEwen et al, 1997), we had interpreted the desipramine-induced decrease in GR binding as representing a greater proportion of GR in the nucleus (Pariante et al, 1997). However, in the light of the present data, these results can be interpreted as an overall decrease in the total number of GRs. Similar to our study, treatment of hippocampal cell culture with antidepressants for $48 \mathrm{~h}$ has been shown to induce GR translocation (Okugawa et al, 1999) and downregulation of GR mRNA (Yau et al, 2001).
We suggest the following model for the in vitro effects of antidepressants on the GR. Treatment with antidepressants inhibits steroid transport, induces GR translocation, and reduces GR expression (Pariante et al, 1997, 2001a; present paper). These three effects could be mediated by the same mechanism. For example, blocking of steroid transport can increase the intracellular levels of steroids from the media - even steroid stripping of serum cannot be absolute (Miller et al, 2002) - thus leading to translocation of the GR. Data showing that PGP inhibitors induce partial GR translocation support this possibility (Prima et al, 2000). Antidepressants could also induce GR translocation through their effect on cAMP-dependent protein kinases (Rangarajan et al, 1992; Chen and Rasenick, 1995; Miller et al, 2002; Blom et al, 2002). Translocation of GR, in turn, could lead to the reduction in GR expression. In fact, GR translocation by both GR agonists and GR antagonists has been associated with a GR downregulation, which takes place over few hours and is because of a reduction in the protein half-life and an inhibition of GR mRNA synthesis; this reduction is temporary and can be followed by a subsequent upregulation (Schmidt and Meyer, 1994). Therefore, it is possible that the inhibition of the transporters precedes the GR downregulation. If cells are coincubated for $24 \mathrm{~h}$ with antidepressants and a glucocorticoid that is expelled by the transporter, like cortisol, an enhanced GR-mediated gene transcription is evident (Pariante et al, 2001a,b). This is because the increase in the intracellular levels of the glucocorticoid overcomes the GR downregulation, and possibly precedes the GR downregulation. However, if cells are treated in experimental conditions that do not elicit the effects on the transporter, the GR downregulation leads to a reduced GR-mediated gene transcription. For example, antidepressants give a reduction in GR-mediated gene transcription when cells are coincubated with corticosterone (Pariante et al, 2001a). Moreover, Miller et al (2002) have recently found that incubation of LMCAT cells with desipramine alone induces a small decrease in the unstimulated GR-mediated gene transcription. Finally, preincubation of cells with an antidepressant (for up to 5 days) leads to approximately $50 \%$ inhibition of GR-mediated gene transcription induced by a subsequent short treatment (1.5-2 h) with dexamethasone or corticosterone (Pariante et al, 1997; Budziszewska et al, 2000). In this case, even if the inhibition of the transporter increases the intracellular levels of dexamethasone (as suggested by our experiments with ${ }^{3} \mathrm{H}$-cortisol), these are unable to compensate for the GR downregulation, possibly because of the short incubation, or possibly because the GR downregulation is present before the glucocorticoid is added (differently than in the coincubation experiments).

Is this model relevant for the effects of antidepressants on the GR and on the HPA axis in animals? Rodents have two isoforms of PGP: the mdrla and the mdr1b. The mdrla PGP is predominantly expressed at the BBB (Regina et al, 1998) and expels cortisol from the brain of rodents, but not corticosterone, which is the endogenous glucocorticoid in these animals (de Kloet et al, 1998; Karssen et al, 2001). However, the mdrlb PGP transports corticosterone (Wolf and Horwitz, 1992; Uhr et al, 2002). This isoform is predominantly expressed in the adrenal and the ovaries 
(Lee et al, 2001), but is also expressed in the brain (Regina et al, 1998), particularly in the hippocampus (Kwan et al, 2002). Although mdrlb PGP has not been detected in brain capillaries (Regina et al, 1998), it is expressed in rat brain endothelial cells in vitro (Felix and Barrand, 2002). Consistent with this, mice that are knockout for mdrla and mdr1b PGP show increased access of corticosterone to the brain (although this effect is smaller than that on cortisol) and increased negative feedback on the HPA axis by corticosterone (Uhr et al, 2002). Therefore, there are intriguing-but still preliminary-lines of evidence suggesting that membrane transport of corticosterone regulates HPA axis function in rodents. By inhibiting membrane steroid transport, antidepressants could directly increase the access of corticosterone to the brain, or the access of other steroids that are transported by PGP, like aldosterone (Ueda et al, 1992), and enhance GR (and MR) activation. Although in the brain the highest expression of PGP has been found at the BBB (Lee et al, 2001), our data show that this effect could also occur directly at the neuronal level. In turn, the increased access of glucocorticoids to the brain could lead to the decrease in HPA axis activity and the GR and MR downregulation described in rats after 3-9 days of treatment with antidepressants (Reul et al, 1993; Yau et al, 2001). This receptor downregulation is consistent with our data in vitro and, theoretically, could explain part of the lag time seen with antidepressants for the onset of their therapeutic action. Chronically, that is, after 14 days or more of treatment, antidepressants induce GR and MR upregulation in the brain (Pariante and Miller, 2001). Although catecholamines upregulate GR and MR expression (Lai et al, 2003), inhibition of catecholamines' uptake seems not to be relevant for the antidepressant-induced GR upregulation. In fact, desipramine increases GR expression in the rat brain even following neurotoxic lesioning of noradrenergic neurones with DSP4 (Rossby et al, 1995). Moreover, antidepressant-induced changes in GR expression in vitro are not blocked by antagonists of alpha- or beta-adrenergic receptors or of $5 \mathrm{HT} 1 \mathrm{a}$ or $5 \mathrm{HT} 2$ serotonergic receptors (Okugawa et al, 1999; Lai et al, 2003). The inhibition of steroid transporters - and the increased access of glucocorticoids to the brain - could explain this GR and MR upregulation, as a compensatory mechanism following the initial downregulation or as a consequence of the reduced HPA axis activity. Consistent with our model, tricyclic antidepressants induce brain MR and GR upregulation at the same concentrations known to inhibit MDR PGP in subcutaneous tumors $(10-20 \mathrm{mg} / \mathrm{kg} / \mathrm{day}$ ) (Merry et al, 1991; Pariante and Miller, 2001). Moreover, pretreatment with nifedipine, an MDR PGP inhibitor, prevents the hippocampal GR upregulation induced by antidepressants (Przegalinski et al, 1993). Inhibition of PGP and other membrane steroid transporters is not receptor mediated and is related to the drugs' physiochemical properties, that is, lipophilicity, electric charge, and ability to accept hydrogen bonds (Ford, 1996; Castaing et al, 2000; Ekins et al, 2002).

In conclusion, we have demonstrated that the antidepressant clomipramine regulates the intracellular levels of cortisol by inhibiting membrane steroid transporters, in LMCAT cells and neurones, that are similar to PGP in their substrates and modulators. In humans, the endogenous glucocorticoid, cortisol, is transported by the PGP at the BBB (Karssen et al, 2001). We propose that antidepressants in humans could inhibit the steroid transporters localized on the BBB and in neurones, and thus increase the access of cortisol to the brain and the negative feedback on the HPA axis. This is consistent with studies showing that treatment with GR and MR agonists (Dinan et al, 1997; Bouwer et al, 2000), including cortisol (DeBattista et al, 2000), has antidepressant effects in humans. Hypothetically, the increased access of cortisol to the brain could balance the reduction of GR function described in patients with major depression (Pariante and Miller, 2001). Or, perhaps, this effect could compensate for a 'reduction' of cortisol levels in the brain of depressed patients that was first (and last) described exactly 30 years ago: 'In studies comparing steroid concentration in eight sudden death controls and six suicide brains, the concentration of cortisol and corticosterone was higher in the controls, in both cerebral cortex and the hypothalamus. (...) All six suicides had a clear history of depressive illness' (Brooksbank et al, 1973).

\section{ACKNOWLEDGEMENTS}

This research was funded by a UK Medical Research Council (MRC) Clinical Training Fellowship to CM Pariante. We are grateful to Andrew Papadopoulos (Affective Disorders Unit, Bethlem Royal Hospital, Beckenham, Kent, UK) for the assessment of cortisol levels in the cell culture media. Dr. Pariante is a Clinical Assistant Professor at the Department of Psychiatry and Behavioral Sciences, Emory University School of Medicine, Atlanta, GA. His research is also funded by a Travel Award from the Wellcome Trust and a Young Investigator Award from the NARSAD.

\section{REFERENCES}

Beck CA, Estes PA, Bona BJ, Muro-Cacho CA, Nordeen SK, Edwards DP (1993). The steroid antagonist RU486 exerts different effects on the glucocorticoid and progesterone receptors. Endocrinology 133: 728-740.

Bergman AM, Pinedo HM, Peters GJ (2001). Steroids affect collateral sensitivity to gemcitabine of multidrug-resistant human lung cancer cells. Eur J Pharmacol 416: 19-24.

Blom JM, Tascedda F, Carra S, Ferraguti C, Barden N, Brunello N (2002). Altered regulation of CREB by chronic antidepressant administration in the brain of transgenic mice with impaired glucocorticoid receptor function. Neuropsychopharmacology 26: 605-614.

Bourgeois S, Gruol DJ, Newby RF, Rajah FM (1993). Expression of an mdr gene is associated with a new form of resistance to dexamethasone-induced apoptosis. Mol Endocrinol 7: 840-851.

Bouwer C, Claassen J, Dinan TG, Nemeroff CB (2000). Prednisone augmentation in treatment-resistant depression with fatigue and hypocortisolaemia: a case series. Depress Anxiety 12: 44-50.

Brooksbank BW, Brammall MA, Shaw DM (1973). Estimation of cortisol, cortisone and corticosterone in cerebral cortex, hypothalamus and other regions of the human brain after natural death and after death by suicide. Steroids Lipids Res 4 : $162-183$

Budziszewska B, Jaworska-Feil L, Kajta M, Lason W (2000). Antidepressant drugs inhibit glucocorticoid receptor-mediated gene transcription - a possible mechanism. Br J Pharmacol 130: 1385-1393. 
Castaing M, Brouant P, Loiseau A, Santelli-Rouvier C, Santelli M, Alibert-Franco $S$ et al (2000). Membrane permeation by multidrug-resistance-modulators and non-modulators: effects of hydrophobicity and electric charge. J Pharm Pharmacol 52: 289-296.

Chen J, Rasenick MM (1995). Chronic treatment of C6 glioma cells with antidepressant drugs increases functional coupling between a G protein (Gs) and adenylyl cyclase. J Neurochem 64: 724-732.

DeBattista C, Posener JA, Kalehzan BM, Schatzberg AF (2000). Acute antidepressant effects of intravenous hydrocortisone and CRH in depressed patients: a double-blind, placebo-controlled study. Am J Psychiatry 157: 1334-1337.

de Kloet ER, Vreugdenhil E, Oitzl MS, Joels M (1998). Brain corticosteroid receptor balance in health and disease. Endocr Rev 19: 269-301.

Dinan TG, Lavelle E, Cooney J, Burnett F, Scott L, Dash A et al (1997). Dexamethasone augmentation in treatment-resistant depression. Acta Psychiatr Scand 95: 58-61.

Ekins S, Kim RB, Leake BF, Dantzig AH, Schuetz EG, Lan LB et al (2002). Application of three-dimensional quantitative structureactivity relationships of P-glycoprotein inhibitors and substrates. Mol Pharmacol 61: 974-981.

Felix RA, Barrand MA (2002). P-glycoprotein expression in rat brain endothelial cells: evidence for regulation by transient oxidative stress. J Neurochem 80: 64-72.

Ford JM (1996). Experimental reversal of P-glycoprotein-mediated multidrug resistance by pharmacological chemosensitisers. Eur J Cancer 32A: 991-1001.

Glotzbach RK, Preskorn SH (1982). Brain concentrations of tricyclic antidepressants: single-dose kinetics and relationship to plasma concentrations in chronically dosed rats. Psychopharmacology (Berl) 78: 25-27.

Herr AS, Wochnik GM, Rosenhagen MC, Holsboer F, Rein T (2000). Rifampicin is not an activator of glucocorticoid receptor. Mol Pharmacol 57: 732-737.

Hery M, Semont A, Fache MP, Faudon M, Hery F (2000). The effects of serotonin on glucocorticoid receptor binding in rat raphe nuclei and hippocampal cells in culture. J Neurochem 74: 406-413.

Hirrlinger J, Konig J, Dringen R (2002). Expression of mRNAs of multidrug resistance proteins (Mrps) in cultured rat astrocytes, oligodendrocytes, microglial cells and neurones. J Neurochem 82 : 716-719.

Holsboer F (2000). The corticosteroid receptor hypothesis of depression. Neuropsychopharmacology 23: 477-501.

Hrdina PD, Dubas TC (1981). Brain distribution and kinetics of desipramine in the rat. Can J Physiol Pharmacol 59: 163-167.

Karssen AM, Meijer OC, van dez Sandt I, de Boer AG, de Lange EC, de Kloet ER (2002). The role of the efflux transporter Pglycoprotein in brain penetration of prednisolone. J Endocrinol 175: 251-260.

Karssen AM, Meijer OC, van dez Sandt I, Lucassen PJ, de Lange EC, de Boer AG, de Kloet ER (2001). Multidrug resistance Pglycoprotein hampers the access of cortisol but not of corticosterone to mouse and human brain. Endocrinology 142: 2686-2694.

Kralli A, Yamamoto KR (1996). An FK506-sensitive transporter selectively decreases intracellular levels and potency of steroid hormones. J Biol Chem 271: 17152-17156.

Kurowski C, Berthold F (1998). Presence of classical multidrug resistance and P-glycoprotein expression in human neuroblastoma cells. Ann Oncol 9: 1009-1014.

Kwan P, Sills GJ, Butler E, Gant TW, Meldrum BS, Brodie MJ (2002). Regional expression of multidrug resistance genes in genetically epilepsy-prone rat brain after a single audiogenic seizure. Epilepsia 43: 1318-1323.

Lai M, McCormick JA, Chapman KE, Kelly PAT, Seckl JR, Yau JLW (2003). Differential regulation of corticosteroid receptors by monoamine neurotransmitters and antidepressant drugs in primary hippocampal culture. Neuroscience, in press.

Lee G, Dallas S, Hong M, Bendayan R (2001). Drug transporters in the central nervous system: brain barriers and brain parenchyma considerations. Pharmacol Rev 53: 569-596.

Leslie EM, Deeley RG, Cole SP (2001). Toxicological relevance of the multidrug resistance protein 1, MRP1 (ABCC1) and related transporters. Toxicology 167: 3-23.

Maes M, Song C, Lin AH, Bonaccorso S, Kenis G, De Jongh R et al (1999). Negative immunoregulatory effects of antidepressants: inhibition of interferon-gamma and stimulation of interleukin10 secretion. Neuropsychopharmacology 20: 370-379.

Marsaud V, Mercier-Bodard C, Fortin D, Le Bihan S, Renoir JM (1998). Dexamethasone and triamcinolone acetonide accumulation in mouse fibroblasts is differently modulated by the immunosuppressants cyclosporin A, FK506, rapamycin and their analogues, as well as by other P-glycoprotein ligands. $J$ Steroid Biochem Mol Biol 66: 11-25.

Matsuoka Y, Okazaki M, Kitamura Y, Taniguchi T (1999). Developmental expression of P-glycoprotein (multidrug resistance gene product) in the rat brain. J Neurobiol 39: 383-392.

McEwen BS, Biron CA, Brunson KW, Bulloch K, Chambers WH, Dhabhar FS et al (1997). The role of adrenocorticoids as modulators of immune function in health and disease: neural, endocrine and immune interactions. Brain Res Brain Res Rev 23: 79-133.

Medh RD, Lay RH, Schmidt TJ (1998). Agonist-specific modulation of glucocorticoid receptor-mediated transcription by immunosuppressants. Mol Cell Endocrinol 138: 11-23.

Meijer OC, de Lange EC, Breimer DD, de Boer AG, Workel JO, de Kloet ER (1998). Penetration of dexamethasone into brain glucocorticoid targets is enhanced in mdr1A P-glycoprotein knockout mice. Endocrinology 139: 1789-1793.

Merry S, Hamilton TG, Flanigan P, Freshney RI, Kaye SB (1991). Circumvention of pleiotropic drug resistance in subcutaneous tumours in vivo with verapamil and clomipramine. Eur J Cancer 27: 31-34.

Miller AH, Vogt GJ, Pearce BD (2002). The phosphodiesterase type 4 inhibitor, rolipram, enhances glucocorticoid receptor function. Neuropsychopharmacology 27: 939-948.

Mulder HS, Pinedo HM, Timmer AT, Rao BR, Lankelma J (1996). Multidrug resistance-modifying components in human plasma with potential clinical significance. J Exp Ther Oncol 1: 13-22.

Nemeroff CB (1996). The corticotropin-releasing factor (CRF) hypothesis of depression: new findings and new directions. Mol Psychiatry 1: 336-342.

O’Donnell D, Francis D, Weaver S, Meaney MJ (1995). Effects of adrenalectomy and corticosterone replacement on glucocorticoid receptor levels in rat brain tissue: a comparison between western blotting and receptor binding assays. Brain Res 687: 133-142.

Okugawa G, Omori K, Suzukawa J, Fujiseki Y, Kinoshita T, Inagaki C (1999). Long-term treatment with antidepressants increases glucocorticoid receptor binding and gene expression in cultured rat hippocampal neurones. J Neuroendocrinol 11: 887-895.

Pariante CM, Makoff A, Lovestone S, Feroli S, Heyden A, Miller AH, Kerwin RW (2001a). Antidepressants enhance glucocorticoid receptor function in vitro by modulating the membrane steroid transporters. Br J Pharmacol 134: 1335-1343.

Pariante CM, Miller AH (2001). Glucocorticoid receptors in major depression: relevance to pathophysiology and treatment. Biol Psychiatry 49: 391-404.

Pariante CM, Papadopoulos AS, Poon L, Checkley SA, English J, Kerwin RW, Lightman S (2002). A novel prednisolone suppression test for the hypothalamic-pituitary-adrenal axis. Biol Psychiatry 51: 922-930. 
Pariante CM, Pearce BD, Pisell TL, Owens MJ, Miller AH (1997). Steroid-independent translocation of the glucocorticoid receptor by the antidepressant desipramine. Mol Pharmacol 52: 571-581.

Pariante CM, Pearce BD, Pisell TL, Sanchez CI, Po C, Su C, Miller AH (1999). The proinflammatory cytokine, interleukin-1alpha, reduces glucocorticoid receptor translocation and function. Endocrinology 140: 4359-4366.

Pariante CM, Pearce BD, Pisell TL, Su C, Miller AH (2001b). The steroid receptor antagonists RU40555 and RU486 activate glucocorticoid receptor translocation and are not excreted by the steroid hormones transporter in L929 cells. J Endocrinol 169: 309-320.

Pepin MC, Beaulieu S, Barden N (1989). Antidepressants regulate glucocorticoid receptor messenger RNA concentrations in primary neuronal cultures. Brain Res Mol Brain Res 6: 77-83.

Pepin MC, Govindan MV, Barden N (1992). Increased glucocorticoid receptor gene promoter activity after antidepressant treatment. Mol Pharmacol 41: 1016-1022.

Prima V, Depoix C, Masselot B, Formstecher P, Lefebvre P (2000). Alteration of the glucocorticoid receptor subcellular localization by non steroidal compounds. J Steroid Biochem Mol Biol 72: 112.

Przegalinski E, Budziszewska B, Siwanowicz J, Jaworska L (1993). The effect of repeated combined treatment with nifedipine and antidepressant drugs or electroconvulsive shock on the hippocampal corticosteroid receptors in rats. Neuropharmacology 32: 1397-1400.

Rangarajan PN, Umesono K, Evans RM (1992). Modulation of glucocorticoid receptor function by protein kinase A. Mol Endocrinol 6: 1451-1457.

Regina A, Koman A, Piciotti M, El Hafny B, Center MS, Bergmann $\mathrm{R}$ et al (1998). Mrp1 multidrug resistance-associated protein and P-glycoprotein expression in rat brain microvessel endothelial cells. I Neurochem 71: 705-715.

Reul JM, Stec I, Soder M, Holsboer F (1993). Chronic treatment of rats with the antidepressant amitriptyline attenuates the activity of the hypothalamic-pituitary-adrenocortical system. Endocrinology 133: 312-320.

Rossby SP, Nalepa I, Huang M, Perrin C, Burt AM, Schmidt DE et al (1995). Norepinephrine-independent regulation of GRII mRNA in vivo by a tricyclic antidepressant. Brain Res 687: 79-82.

Sanchez ER, Hu JL, Zhong S, Shen P, Greene MJ, Housley PR (1994). Potentiation of glucocorticoid receptor-mediated gene expression by heat and chemical shock. Mol Endocrinol 8: 408-421.

Schmidt TJ, Meyer AS (1994). Autoregulation of corticosteroid receptors. How, when, where, and why? Receptor 4: 229-257.

Shabbits JA, Krishna R, Mayer LD (2001). Molecular and pharmacological strategies to overcome multidrug resistance. Expert Rev Anticancer Ther 1: 585-594.
Sisodiya SM, Lin WR, Harding BN, Squier MV, Thom M (2002). Drug resistance in epilepsy: expression of drug resistance proteins in common causes of refractory epilepsy. Brain 125: 22-31.

Steiner AE, Wittliff JL (1985). A whole-cell assay for glucocorticoid binding sites in normal human lymphocytes. Clin Chem 31: $1855-1860$.

Szabo D, Szabo Jr G, Ocsovszki I, Aszalos A, Molnar J (1999). Anti-psychotic drugs reverse multidrug resistance of tumor cell lines and human AML cells ex-vivo. Cancer Lett 139: $115-119$.

Ueda K, Okamura N, Hirai M, Tanigawara Y, Saeki T, Kioka N et al (1992). Human P-glycoprotein transports cortisol, aldosterone, and dexamethasone, but not progesterone. J Biol Chem 267: 24248-24252.

Uhr M, Holsboer F, Muller MB (2002). Penetration of endogenous steroid hormones corticosterone, cortisol, aldosterone and progesterone into the brain is enhanced in mice deficient for both mdrla and mdrlb P-glycoproteins. J Neuroendocrinol 14: 753-759.

Uhr M, Steckler T, Yassouridis A, Holsboer F (2000). Penetration of amitriptyline, but not of fluoxetine, into brain is enhanced in mice with blood-brain barrier deficiency due to mdrla Pglycoprotein gene disruption. Neuropsychopharmacology 22: 380-387.

Varga A, Nugel H, Baehr R, Marx U, Hever A, Nacsa J et al (1996). Reversal of multidrug resistance by amitriptyline in vitro. Anticancer Res 16: 209-211.

Vedder H, Bening-Abu-Shach U, Lanquillon S, Krieg JC (1999). Regulation of glucocorticoid receptor-mRNA in human blood cells by amitriptyline and dexamethasone. J Psychiatr Res 33: 303-308.

Williamson R, Scales T, Clark BR, Gibb G, Reynolds CH, Kellie S et al (2002). Rapid tyrosine phosphorylation of neuronal proteins including tau and focal adhesion kinase in response to amyloid-beta peptide exposure: involvement of Src family protein kinases. J Neurosci 22: 10-20.

Wolf DC, Horwitz SB (1992). P-glycoprotein transports corticosterone and is photoaffinity-labeled by the steroid. Int J Cancer 52: $141-146$

Xia Z, Bergstrand A, DePierre JW, Nassberger L (1999). The antidepressants imipramine, clomipramine, and citalopram induce apoptosis in human acute myeloid leukemia HL60 cells via caspase- 3 activation. J Biochem Mol Toxicol 13: 338-347.

Yau JL, Noble J, Hibberd C, Seckl JR (2001). Short-term administration of fluoxetine and venlafaxine decreases corticosteroid receptor mRNA expression in the rat hippocampus. Neurosci Lett 306: 161-164. 